\title{
HJV wt Allele
}

National Cancer Institute

\section{Source}

National Cancer Institute. HN wt Allele. NCI Thesaurus. Code C113603.

Human HJV wild-type allele is located in the vicinity of $1 \mathrm{q} 21.1$ and is approximately $19 \mathrm{~kb}$ in length. This allele, which encodes hemojuvelin protein, is involved in both bone morphogenetic protein signaling and iron metabolism. Mutation of the gene is associated with hemochromatosis type $2 \mathrm{~A}$. 